\title{
Application of B Splines to Identification of the Movement Equations of the Floating Objects
}

\section{Primjena B-splajna na identifikaciju jednadžbi kretanja plovnih objekata}

\author{
Marek Zellma \\ Polish Naval Academy \\ Faculty of Mechanical-Electrical \\ Engineering \\ Poland \\ E-mail:m.zellma@amw.gdynia.pl \\ Agata Załęska-Fornal
Polish Naval Academy
Faculty of Mechanical-Electrical
Engineering
Poland
E-mail:a.fornal@amw.gdynia.pl
}

DOI 10.17818/NM/2021/1.7 UDK 517.926:629.585

Professional paper / Stručni rad

Paper accepted / Rukopis primljen: 11. 8. 2019.

\section{Summary}

The paper presents the possibilities of using B-splines to determine a mathematical model in the form of linear differential equations describing the change of the motion parameters of floating objects depending on the values of the control signals. The elaborated identification system is a collection of algorithms including: approximation of input and output signals, optimal selection of differential equation coefficients and model verification. The basic spline functions were used to approximate the values of the input and output signals. The developed method was illustrated by an example of identification of underwater submarine motion equations describing the change in draft depth and trim angle depending on the difference between buoyancy force and ship's weight.

\section{Sažetak}

U radu su predstavljene mogućnosti korištenja B-splajn krivulja za određivanje matematičkog modela u obliku linearnih diferencijalnih jednadžbi koje opisuju promjenu parametara gibanja plovnih objekata ovisno o vrijednostima upravljačkih signala. Razrađeni identifikacijski sustav zbirka je algoritama koji uključuju: aproksimaciju ulaznih i izlaznih signala, optimalan odabir koeficijenata diferencijalne jednadžbe i provjeru modela. Osnovne splajn-funkcije korištene su za približavanje vrijednosti ulaznih $i$ izlaznih signala. Razvijena metoda ilustrirana je primjerom identifikacije jednadžbi gibanja podvodnih podmornica koje opisuju promjenu dubine gaza i kuta trima, ovisno o razlici između sile uzgona i težine broda.

\section{KEY WORDS}

B splines

motion parameters

linear differential equations

identification

\section{INTRODUCTION / Uvod}

The rapid development of technical progress creates the need to identify control objects. Most objects can be treated as dynamical systems. Intuitively, a dynamical system is understood as an object considered from the point of view of its behavior over time. Identification is closely related to the mathematical modeling of real systems and its task is to create some methods for establishing the best mathematical model in a specific sense. The course of actions, the effect of which is the construction of a mathematical model, recognized in accordance with the adopted evaluation criterion as sufficiently well describing the behavior of a real object, we will call the identification system.

The identification system of the dynamic systems includes: a) the description of the inputs and outputs;

b) the mathematical model of the relationship between input and output signals;

c) the model verification

The mathematical model of the real system correctly obtained as a result of identification enables to determine the control algorithm as well as the design of devices implementing that algorithm.

Despite many works devoted to the identification of dynamical systems the new methods of identification systems suitable for electronic computing are still necessary.
The Authors use splines to describe the signals. The first spline functions presented by I.J.Schoenberg in 1946 were 'glued up' from pieces of third-degree polynomials.

In [2], [6], [10], [11] to identify the dynamical systems described by the linear differential equations the polynomial spline functions were applied.

In practice it is very useful to present polynomial spline functions by means of $B$ - splines (B - functions) ([6], [9]). Their application in the description of signals and the identification of systems was presented in the articles [2], [9], [12]

The theory of splines is currently a very extensive mathematical theory and it is developing in an algebraic and variational direction. In the algebraic approach splines are treated as a set of functions with the same structure. The structure includes the so-called L - splines. The application of those splines for identification has been presented in [13]

In the variational approach the functions that minimize some specified functionals are called splines. That group includes smoothing spline functions. In [14] the smoothing splines were used for signals description. They can also be applied for the identification of the dynamical systems described by differential equations up to the second order. 
The algorithm presented in this paper enables the identification of dynamic systems described by the differential equations of the $n$-th order.

The purpose of the identification is to establish a mathematical model that describes the considered phenomena occurring in real systems as part of the adopted assessment criteria in the way. For a wide class of dynamical systems, the dependence between input $u \in U$ and $y \in Y$ output quantities can be described by means of the linear differential equation of $n$-th order with constant coefficients

$a_{n} y^{(n)}(t)+\cdots+a_{1} y^{\prime}(t)+a_{0} y(t)=b_{m} u^{(m)}(t)+b_{m-1} u^{(m-1)}(t)+\cdots a_{1} u^{\prime}(t)+u(t)(1)$ where

$$
a_{i}, b_{j} \in R, y^{\prime}=\frac{d}{d t} y(t), \quad y^{(n)}=\frac{d^{(n)}}{d t^{n}} y(t), \quad m \leq n .
$$

The set $U$ is called the space of inputs of (1) while its elements $u$ are called inputs signals. The set $Y$ is called the space of outputs while its elements $y$ are called outputs. The response of the system is determined by:

- the initial conditions;

input quantities (forced inputs);

parameters which characterized the inner systems structure and which are appearing as coefficients in equations.

Let $\hat{u}_{l}=\hat{u}_{l}(t)$ and $\hat{y}_{l}=\hat{y}_{l}(t), l=1,2, \ldots, n_{1}$ denote the signals determined by approximation of values of inputs $\tilde{u}_{1}\left(\tau_{k}\right), \ldots, \tilde{u}_{n_{1}}\left(\tau_{k}\right)$ and values $\tilde{y}_{1}\left(\tau_{k}\right), \ldots, \tilde{y}_{n_{1}}\left(\tau_{k}\right)$ of outputs (which are known from measurements on the real system)) at the moments $\tau_{k}, \quad k=0,1, \ldots, n_{2}$ where

$$
\tau_{k} \in\left[t_{0}, t_{N}\right], \quad t_{0}=\tau_{0}, \quad t_{N}=\tau_{n_{2}}, \quad k=0,1, \ldots, n_{2} .
$$

As the example of the equation (1) we can the jest equation of the ship's maneuverability

$$
T_{1} T_{2} \psi^{\prime \prime \prime}(t)+\left(T_{1}+T_{2}\right) \psi^{\prime \prime}(t)+\psi^{\prime}(t)=K\left(T_{3} \delta^{\prime}(t)+\delta(t)\right)
$$

which is called 'Nomoto 2nd order model' ([1], [5], [7], [8]) describing the relationship between the rudder deflection angle $\delta(t)$ and the course angle $\psi(t)$. The coefficients $K_{1}, T_{1}, T_{2}, T_{3}$ characterize the ship's steering ability.

The developed method will be illustrated by an example of the identification of the differential equation describing the change of the increment of the submersion depth and the increment of the trim angle of a submarine depending on the weight of the water taken by the compensation tank of torpedo tubes.

\section{THE ALGORITHM OF APPROXIMATION BY MEANS OF B SPLINES OF II TYPE / Algoritam aproksimacije pomoću B splajna tipa II}

Let $\Delta_{N}$ be the system of points $t_{i}, \quad i \in \overline{1, N}$ dividing the interval $\left[t_{0}, t_{N}\right]$ into $N$ subintervals i.e.

$$
\Delta_{N}: \quad t_{0}<t_{1}<\cdots t_{n-1}<t_{N}
$$

Let $C^{k}\left[t_{0}, t_{N}\right]$ denotes the set of continuous functions $\mathrm{f}$ and their derivatives

$$
f^{\prime}, f^{\prime \prime}, \cdots, f^{(k)},
$$

of real variable $t$ defined on the interval $\left[t_{0}, t_{N}\right]$.

Definition 1. The function $s_{n, v}=s_{n, v}\left(t, \Delta_{N}\right)$ is called the spline of $n$-th order with the fault $V$ (integer number $0 \leq v \leq n+1$ ) with knots (3) if:

a. $S_{n, v}$ is a polynomial of the order at most $r$ in every subinterval $\left[t_{i}, t_{i+1}\right]$ for $i \in \overline{0, N-1}$,

$$
\text { b. } s_{r, v}(t) \in C^{n-v}\left[t_{0}, t_{N}\right] \text {. }
$$

Let us expand the division $\Delta_{N}$ of $\left[t_{0}, t_{N}\right]$ by points:

$$
t_{-r}<\cdots<t_{-1}<t_{0} ; \quad t_{N}<t_{N+1}<\cdots<t_{N+r} .
$$

We accept that

$t_{-i}=t_{0}-i\left(t_{1}-t_{0}\right) \quad t_{N+i}=t_{N}+i\left(t_{N}-t_{N-1}\right) \quad i \in \overline{1, r}$.

In practical, real problems the B-splines of II type are usually applied.

The base of B-splines of II type of 0 order has the following form

$$
B_{0}^{i}(t)=\left\{\begin{array}{ccc}
0 & \text { for } & \mathrm{t}<\mathrm{t}_{\mathrm{i}} \\
1 & \text { for } & \mathrm{t}_{\mathrm{i}} \leq t<t_{i+1}, \quad i=0,1, \ldots, N-1 . \\
0 & \text { for } & \mathrm{t} \geq \mathrm{t}_{\mathrm{i}+1}
\end{array}\right.
$$

The base of splines of II type: $B_{r}^{i}, \quad i \in \overline{-r, N-1}$ for $\mathrm{n}>1$ can be determined by using the De Boor equations [9]:

$$
B_{r}^{i}(t)=\frac{t-t_{i}}{t_{i+r}-t_{i}} B_{r-1}^{i}(t)+\frac{t_{i+r+1}-t}{t_{i+r+1}-t_{i+1}} B_{r-1}^{i+1}(t), \quad i \in \overline{-r, N-1} .
$$

On the basis of the measurements $\tilde{y}_{k}$ determined in the moments $\tau_{k} \in \overline{0, n_{2}}$ of the real signal $y=y(t)$ we are going to define a function

$$
\hat{y}=\sum_{i=-r}^{N-1} c_{i} B_{r}^{i}(t)
$$

such that for any fixed $\tau_{k} \in \overline{0, n_{2}}$ the random variable $\tilde{y}_{k}$ has a normal distribution with the mean value

$$
\hat{y}_{k}=\sum^{N-1} c_{i} B_{r}^{i}\left(\tau_{k}\right)
$$

and standard deviation $\sigma$. Moreover, we assume that the random variables $y_{k}$ are independent.

The coefficients $c_{i}, i \in \overline{-r, N-1}$ will be determined using the maximum likelihood method by minimalizing the density function

$$
L=\frac{1}{\left(2 \pi \sigma^{2}\right)^{n_{2} / 2}} \exp \left(-\frac{1}{2 \sigma^{2}} \sum_{k=0}^{n_{2}}\left[\widetilde{y}_{k}-\sum_{i=-n}^{N-1} c_{i} B_{r}^{i}\left(\tau_{k}\right)\right]^{2}\right)
$$

of random variables $y_{k}, k \in \overline{0, n_{2}}$.

The problem of choice the optimal coefficients $c_{i}, i \in \overline{-r, N-1}$ minimalizing the density function (7) comes down to solve the systems of equations:

$$
\sum_{v=-r}^{N-1} c_{l, \nu} v_{v \mu}=w_{\mu}, \quad \mu \in \overline{-r, N-1}, \quad l \in \overline{1, n_{1}}
$$

where

$$
\begin{gathered}
v_{v \mu}=\sum_{k=0}^{n_{2}} B_{r}^{v}\left(\tau_{k}\right) B_{r}^{\mu}\left(\tau_{k}\right), \quad v, \mu \in \overline{-r, N-1}, \quad v_{v \mu}=0 \text { for }|v-\mu| \geq r+1 \\
w_{l, v}=\sum^{n_{2}} \tilde{y}_{l}\left(\tau_{k}\right) B_{r}^{\mu}\left(\tau_{k}\right) .
\end{gathered}
$$

The matrix $\left\lfloor v_{v \mu}\right\rfloor_{(r+N) x(r+n)}$ of systems of equations (8) is symmetric, regular and ribbon (the so-called $(2 r+1)$ - diagonal). Therefore the coefficients $c_{i}, i \in \overline{-r, N-1}$ can be determined recursively [10].

\section{ALGORITHM OF CHOOSING THE OPTIMAL COEFFICIENTS OF THE DYNAMIC SYSTEM / Algoritam izbora optimalnih koeficijenata dinamičkog sustava}

To choose the optimal coefficients we present (1) as

$\alpha_{0} y(t)+\alpha_{1} y^{\prime}(t)+\cdots+\alpha_{(n-1)} y^{(n-1)}(t)+$

$+\alpha_{n} y^{(n)}(t)+\alpha_{n+1} u^{\prime}(t)+\cdots+\alpha_{n+m} u^{(m)}(t)=u(t)$,

where

$\alpha_{0}:=a_{0}, a_{1}:=a_{1}, \ldots, \alpha_{n}:=a_{n}, \alpha_{n+1}:=$

$=-b_{1}, \alpha_{n+2}:=-b_{2}, \ldots, \alpha_{n+m}:=-b_{m}$. 
By identification of the dynamic system (1), we understand the problem of choice of the coefficients of (1) with determined signals

$$
\hat{u}_{l}=\sum_{\mu=-r}^{N-1} C_{l, \mu} B_{r}^{\mu}, \quad \hat{y}_{l}=\sum_{\mu=-r}^{N-1} c_{l, \mu} B_{r}^{\mu}, \quad l=\overline{1, n_{1}}
$$

in such a way that the functional (the identification index):
$J\left(\alpha_{0}, \ldots, \alpha_{n+m}\right)=\sqrt{\sum_{l=0}^{n_{1}} \int_{t_{0}}^{t_{N}}\left[\alpha_{0} \hat{y}_{l}(t)+\cdots+\alpha_{n} \hat{y}_{l}^{(n)}(t)+\alpha_{n+1} \hat{u}_{l}^{\prime}(t)+\cdots+\alpha_{n+m} \hat{u}_{l}^{(m)}(t)-\hat{u}_{l}(t)\right] d t(11)}$ reaches its minimum value.

The problem of choice the optimal coefficients $\alpha_{0}^{0}, \ldots, \alpha_{m+n}^{0}$ of (9) minimalizing the functional (11) comes down to solve the system of linear equations (included in the scheme of the below presented algorithm).

\section{Algorithm of the identification of the dynamic system / Algoritam identifikacije dinamičkog sustava}

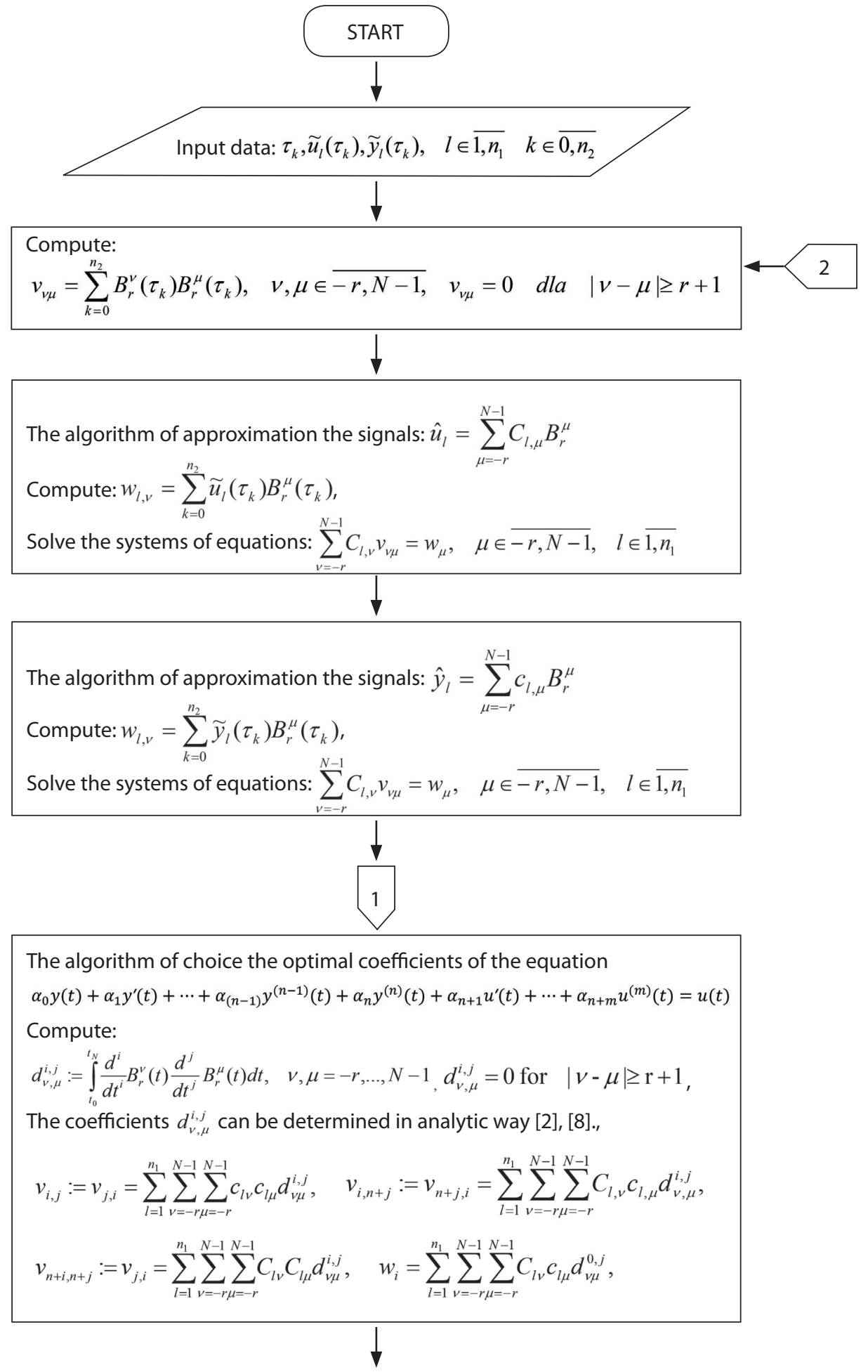




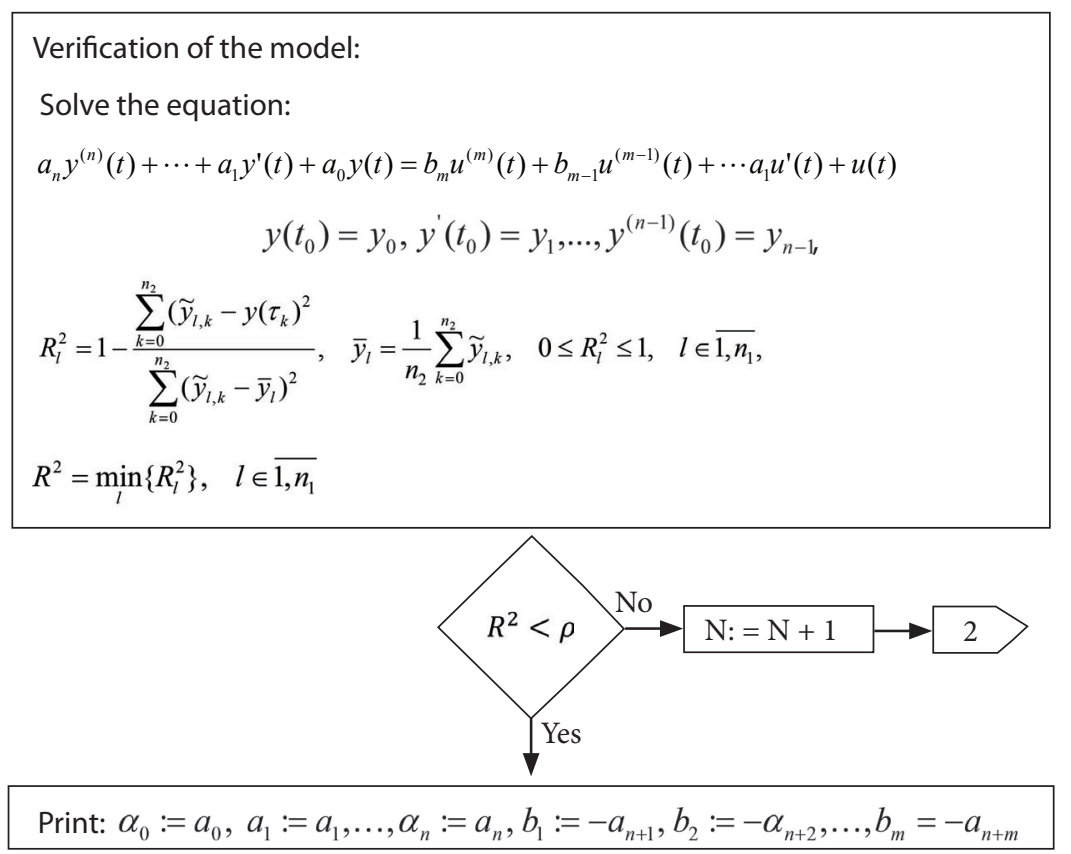

A computer program in Turbo Pascal was written for identification the coefficients of the differential equations up to the fourth order. In the example below, Mathematica program was used to solve the differential equations and signal plots.

\section{NUMERICAL EXAMPLE / Numerički primjer}

The submarine, flowing on the surface of the sea, is subjected to the same laws as any surface ship. There are two forces acting on the ship: the force of gravity $P$ directed downwards and the buoyancy force $D$ directed upward. The difference $A=D-P$ between the buoyancy force and the force of gravity $P$ is often referred to as residual buoyancy. If $A>0$ then we deal with positive residual buoyancy and the ship will have a tendency to float to the surface. If $A<0$ then the buoyancy is negative and the ship will tend to increase its depth.

If $A=0$ then we have the case of the so-called zero buoyancy.

The influence of the residual buoyancy on the behavior of the ship depends on its value, its place of occurrence (distance from the center of gravity of the ship) and the speed of the ship.

To balance the force of gravity $P$ with buoyancy force $D$ the regulating trim and compensating tanks are used. Filling those tanks with water from behind the side or removing water overboard causes that ship's weight increases or decreases.

In order to keep the submarine at the intended depth and to change the draft, depth rudders as well as regulation and trim systems are commonly used. Through the depth rudders and the regulation and trim system, independent constraints are generated to control the longitudinal movement of the ship in weariness. Due to the variety of physical (hydrodynamic) phenomena affecting the movement of the real submarine, the motion equations obtained on the basis of mathematical dependences describing physical (hydrodynamic) phenomena define only the movement of a specific submarine. In this case, we will determine certain equations of motion of the submarine based on the measurements of the depth of immersion $\widetilde{h}_{i^{\prime}}$ the trim angle $\widetilde{\psi}_{i}$, the weight of water $\tilde{A}_{i}$ flowing into the compensation tanks in $t_{i}, i=0,1, \ldots, n_{1}$ moments of time.

The computer program is applied to determine the differential equations describing the dependence of changes in the depth of immersion and the increment of the trim angle of the submarine on the weight of water assumed by the aft reservoir of the torpedo tubes at constant speed $v=2.93\left[\frac{\mathrm{m}}{\mathrm{c}}\right] \quad(5,7[\mathrm{w}])$.

The measured data are presented in Table 1. where $\tilde{A}_{l}\left(\tau_{k}\right), \quad l=1,2,3$ denotes the measured weight of water the aft reservoir of the torpedo tubes at the moment of time $\tau_{k}$, while $\widetilde{h}_{l}\left(\tau_{k}\right)$ and $\widetilde{\psi}_{l}\left(t_{k}\right)$ denote the measured values of immersion depth and trim angle of the submarine correspondingly. Those data were approximated by means of the B-splines of $3^{\text {rd }}$ order and they were denoted as $\hat{A}_{l}(t), \hat{h}_{l}(t), \hat{\Psi}_{l}(t)$.

Table 1. The values of the immersion depth and the OP trim angle depend on the weight of the water flowing into the aft compensation tank of the torpedo tubes

Tablica 1. Vrijednosti dubine uranjanja i OP kuta trima ovise o težini vode koja teče u krmeni kompenzacijski spremnik torpednih cijevi

\begin{tabular}{|c|c|c|c|c|c|c|c|c|c|}
\hline & \multicolumn{4}{|c|}{ Measurement 1 } & \multicolumn{3}{|c|}{ Measurement 2 } & \multicolumn{3}{|c|}{ Measurement 3 } \\
\hline$\tau_{k}$ & $\tilde{A}_{1 k}$ & $\tilde{h}_{1 k}$ & $\tilde{\psi}_{1 k}$ & $\tilde{A}_{2 k}$ & $\tilde{h}_{2 k}$ & $\tilde{\psi}_{2 k}$ & $\tilde{A}_{3 k}$ & $\tilde{h}_{3 k}$ & $\tilde{\psi}_{31 k}$ \\
\hline$[s]$ & {$[k g]$} & {$[m]$} & {$[\ldots$} & {$[k g]$} & {$[m]$} & {$\left[\ldots{ }^{0}\right]$} & {$[k g]$} & {$[m]$} & {$[\ldots$.} \\
\hline 0 & 0 & 44.6 & 0. & 0 & 42.0 & 0 & 0 & 41.6 & 0 \\
\hline 15 & 200 & 44.5 & 0.2 & 200 & 41.6 & 0.5 & 200 & 41.2 & 0.5 \\
\hline 30 & 390 & 44.3 & 1.2 & 380 & 41.5 & 1.2 & 400 & 40.91 & 1.1 \\
\hline 45 & 600 & 43.8 & 2.5 & 580 & 40.9 & 2.7 & 600 & 40.2 & 2.8 \\
\hline 60 & 780 & 42.8 & 3.7 & 760 & 39.6 & 3.5 & 750 & 39.2 & 3.7 \\
\hline 75 & 980 & 41.7 & 5.0 & 960 & 37.8 & 5.5 & 950 & 38.2 & 4.7 \\
\hline 90 & 1110 & 40.1 & 6.5 & 1120 & 36.6 & 7.0 & 1150 & 37.0 & 6.7 \\
\hline 105 & 1350 & 38.2 & 8.0 & 1350 & 34.4 & 8.0 & 1350 & 35.8 & 8.2 \\
\hline 120 & 1350 & 36.4 & 8.9 & 1350 & 32.6 & 9.2 & 1350 & 34.0 & 9.0 \\
\hline 135 & 1350 & 35.2 & 9.2 & 1350 & 31.2 & 9.0 & 1350 & 32.7 & 9.2 \\
\hline 150 & 1350 & 33.8 & 9.0 & 1350 & 29.8 & 9.2 & 1350 & 31.3 & 9.4 \\
\hline 165 & 1350 & 32.2 & 8.5 & 1350 & 28.8 & 9.0 & 1350 & 30.0 & 9.2 \\
\hline 180 & 1350 & 30.9 & 8.4 & 1350 & 27.7 & 8.2 & 1350 & 28.8 & 8.2 \\
\hline 195 & 1350 & 29.8 & 8.2 & 1350 & 27.2 & 8.2 & 1350 & 27.8 & 8.5 \\
\hline & & & & & & & & & \\
\hline
\end{tabular}

The dependence of the increase change $\Delta h(t)=h\left(t_{0}\right)-h(t)$ depth of immersion of the ship and changes in the increment $\Delta \psi(t)=\psi(t)-\psi\left(t_{0}\right)$ of the trim angle and change of the weight of water $A(t)$ inflowing to the torpedo tubes compensation tanks under the influence of outboard pressure can be adequately 
described by the linear differential equations of the second order $66853.334988 \frac{d^{2}}{J_{t^{2}}} \Delta h(t)+8561.3632660 \frac{d}{J_{t}} \Delta h(t)+49.038265538 \Delta h(t)=A(t)(12)$ $45048.55 \frac{d^{2}}{d t^{2}} \Delta \psi(t)+1653.22872044 \frac{d}{d t} \Delta \psi(t)+159.16073506 \Delta \psi(t)=A(t)(13)$

The solutions of (12) and (13) when

$$
A(t)=\hat{A}_{1}(t), \Delta h(0)=\frac{d}{d t} \Delta h(0)=0, \Delta \psi(0)=\frac{d}{d t} \Delta \psi(0)=0 ;
$$

are shown in Table 2. and on Figure 3. In that case the maximal errors between the values of depth increments $\Delta \tilde{h}\left(\tau_{k}\right)$, trim angle $\Delta \tilde{\psi}\left(\tau_{k}\right)$ determined from the measurements and the values $\Delta \psi_{m}\left(\tau_{k}\right)$ and $\Delta h_{m}\left(\tau_{k}\right)$ determined from the equations (12) and (13) are equal:

$\max _{\mathrm{k}}\left|\Delta \widetilde{h}_{m}\left(\tau_{k}\right)-\Delta h_{m}\left(\tau_{k}\right)\right|=0.3[\mathrm{~m}], \max _{\mathrm{k}}\left|\Delta \widetilde{\psi}\left(\tau_{k}\right)-\Delta \psi_{m}\left(\tau_{k}\right)\right|=0.5[\mathrm{~m}]$ correspondingly.
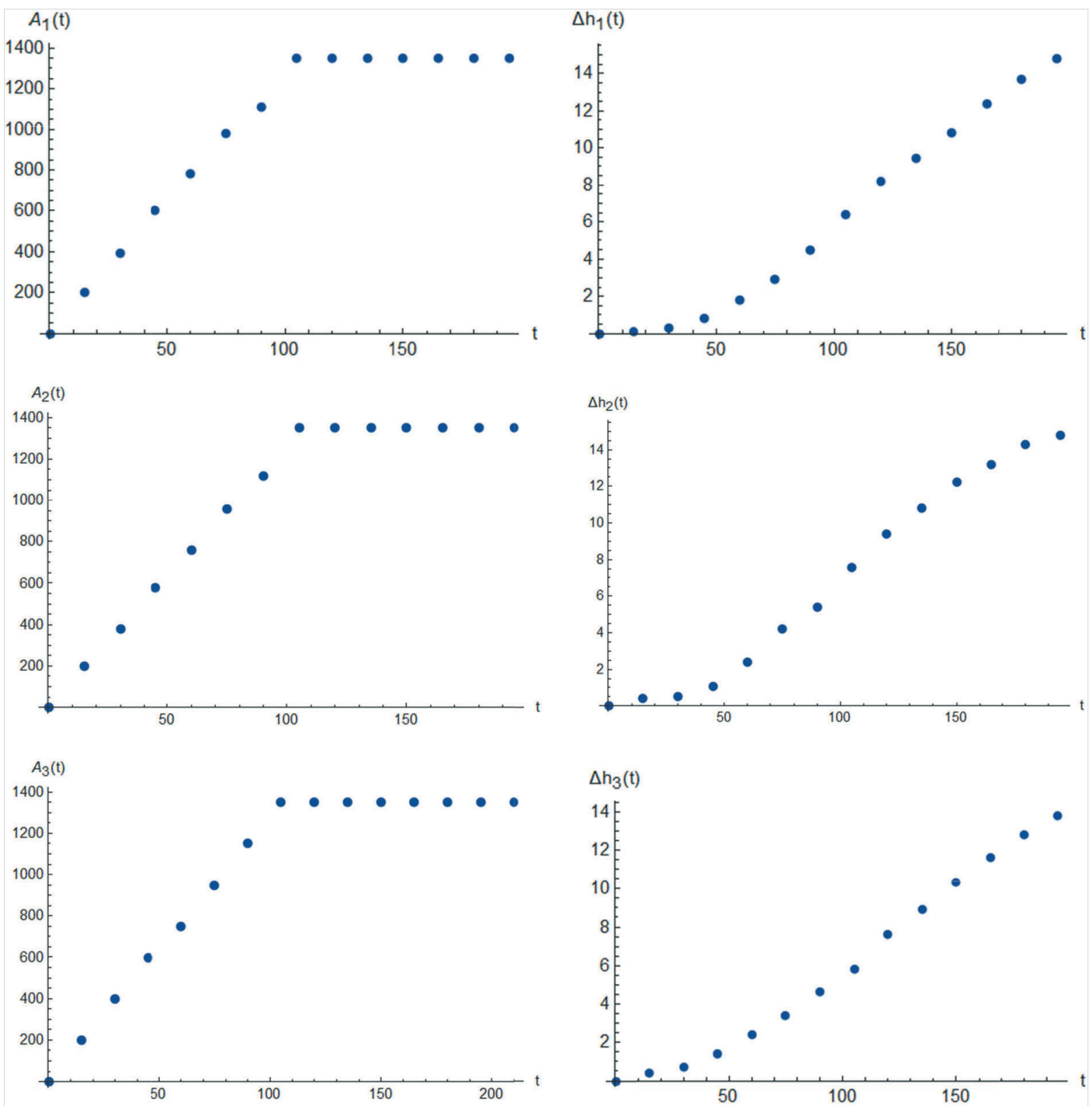

Figure 2 Changes in the increment $\Delta h(t)=h\left(t_{0}\right)-h(t)$ of the submergence depth of the ship from the change $A(t)$ in the weight of water flowing into the torpedo tube compensation.

Slika 2. Promjene u povećanju $\Delta h(t)=h\left(t_{0}\right)-h(t)$ dubine uronjenosti broda od promjene $A(t)$ težine vode koja teče u kompenzacijsku cijev torpeda 
Table 2. Results of verification of differential equations (15) - (16) describing the change of ship's depth and trim angle Tablica 2. Rezultati provjere diferencijalnih jednadžbi (15) - (16) koje opisuju promjenu dubine broda i kuta trima

\begin{tabular}{|c|c|c|c|c|c|c|c|c|c|}
\hline$\tau_{k}$ & $\tilde{A}_{1 k}$ & $\tilde{h}_{1 k}$ & $\Delta \widetilde{h}_{1 k}$ & $\Delta h_{m 1 k}$ & $\Delta \widetilde{h}_{k}-\Delta h_{\eta 1 k}$ & $h_{m 1 k}$ & $\widetilde{\psi}_{1 k}$ & $\psi_{m 1 k}$ & $\widetilde{\psi}_{1 k}-\psi_{m 1 k}$ \\
\hline$[s]$ & {$[k g]$} & {$[m]$} & {$[m]$} & {$[m]$} & {$[m]$} & {$[m]$} & {$\left[\ldots{ }^{0}\right]$} & {$[m]$} & {$\left[\ldots{ }^{0}\right]$} \\
\hline 0 & 0 & 44.6 & 0.0 & 0.00 & 0.0 & 44.60 & 0.0 & 0.0 & 0 \\
\hline 15 & 200 & 44.5 & 0.1 & 0.08 & 0.02 & 44.52 & 0.2 & 0.14 & 0.06 \\
\hline 30 & 390 & 44.3 & 0.3 & 0.42 & -0.12 & 44.18 & 1.2 & 0.89 & 0.31 \\
\hline 45 & 600 & 43.8 & 0.8 & 1.06 & -0.26 & 43.54 & 2.5 & 2.26 & 0.24 \\
\hline 60 & 780 & 42.8 & 1.8 & 2.00 & -0.20 & 42.60 & 3.7 & 3.93 & -0.23 \\
\hline 75 & 980 & 41.7 & 2.9 & 3.20 & -0.30 & 41.40 & 5.0 & 5.50 & -0.50 \\
\hline 90 & 1110 & 40.1 & 4.5 & 4.61 & -0.10 & 40.00 & 6.5 & 6.80 & -0.30 \\
\hline 105 & 1350 & 38.2 & 6.4 & 6.19 & 0.21 & 38.41 & 8.0 & 7.72 & 0.08 \\
\hline 120 & 1350 & 36.4 & 8.2 & 7.95 & 0.25 & 36.65 & 8.9 & 8.61 & 0.29 \\
\hline 135 & 1350 & 35.2 & 9.4 & 9.63 & -0.23 & 34.97 & 9.2 & 9.07 & 0.13 \\
\hline 150 & 1350 & 33.8 & 10.8 & 11.17 & -0.37 & 33.43 & 9.0 & 8.99 & 0.01 \\
\hline 165 & 1350 & 32.2 & 12.4 & 12.58 & -0.18 & 32.02 & 8.5 & 8.66 & -0.11 \\
\hline 180 & 1350 & 30.9 & 13.7 & 13.87 & -0.17 & 30.73 & 8.4 & 8.36 & 0.04 \\
\hline 195 & 1350 & 29.8 & 14.8 & 15.05 & -0.24 & 29.55 & 8.2 & 8.26 & -0.06 \\
\hline
\end{tabular}

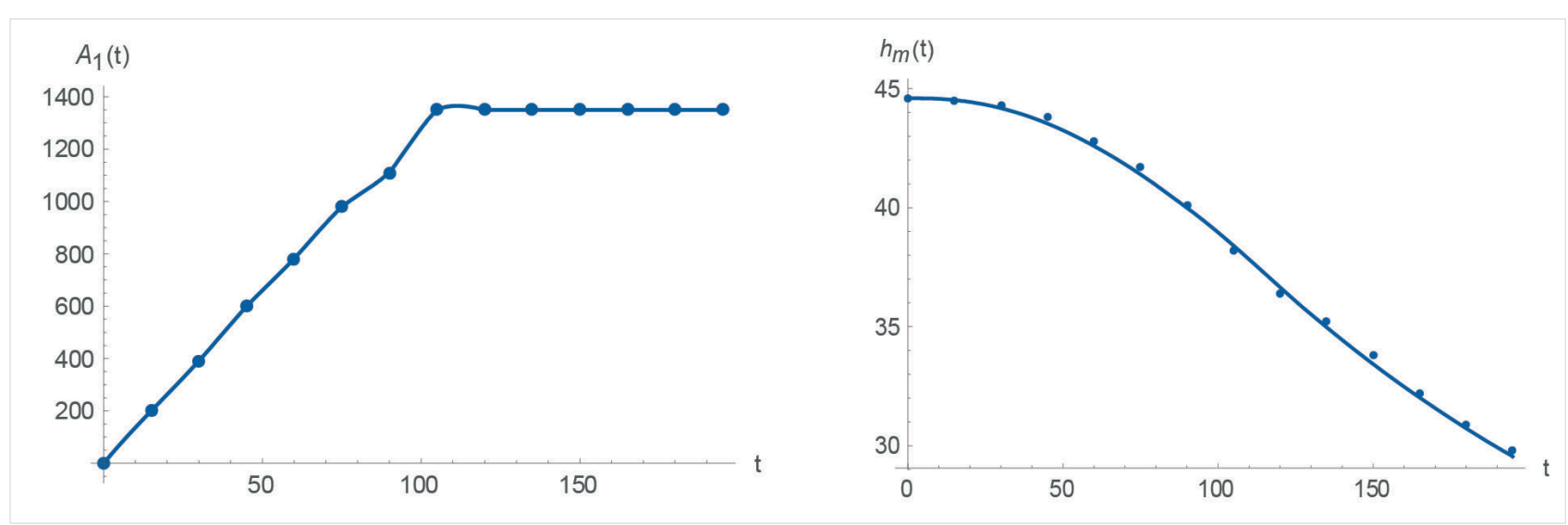

Figure 3. Solution $h_{m}(t)=\tilde{h}\left(t_{0}\right)-\Delta h_{m}(t)$ of the initial problem Slika 3. Rješenje $h_{m}(t)=\tilde{h}\left(t_{0}\right)-\Delta h_{m}(t)$ početnog problema
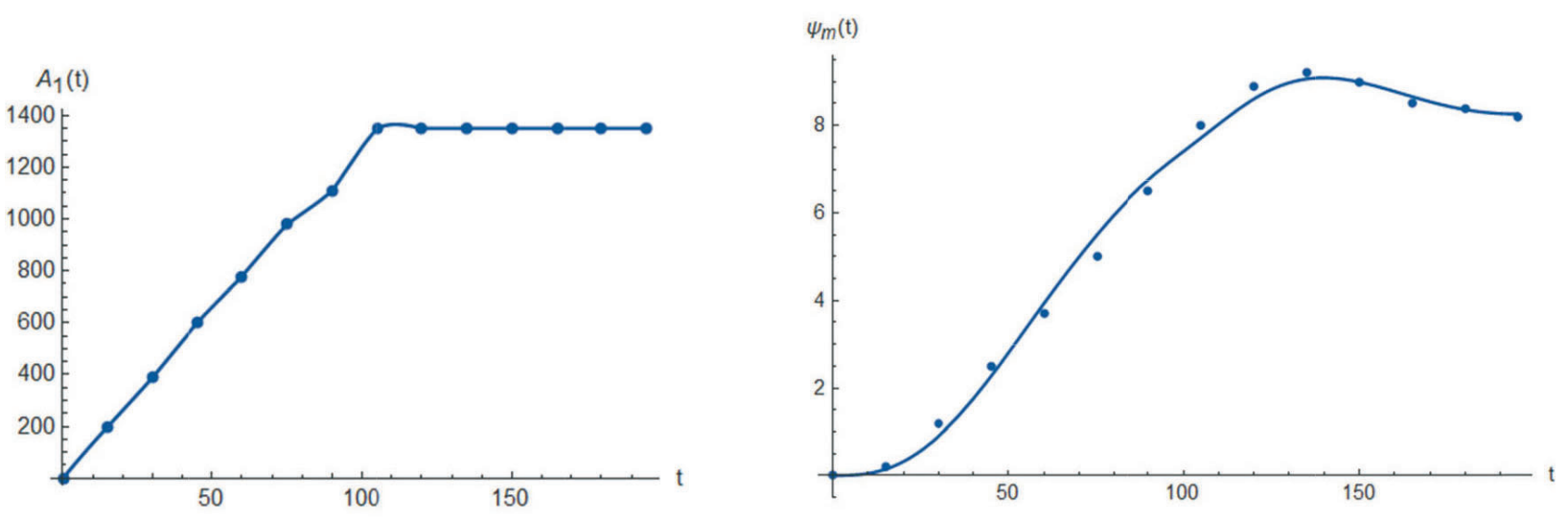

Figure 4 Change of the trim angle determined from the solution of the equation (13). Slika 4. Promjena kuta trima određena iz rješenja jednadžbe (13)

To determine the optimal number $N$ of base regression functions (7), you can use the $F$ test. To this aim, we calculate

where

$$
F=\frac{S_{2}^{2}-S_{1}^{2}}{S_{2}^{2}} \cdot \frac{n_{1}-N_{2}-3}{N_{2}-N_{1}},
$$

$S_{1}^{2}=\sum_{k=0}^{n_{1}}\left[\hat{y}_{k}^{1}-\bar{y}_{1}\right]^{2}, \quad S_{2}^{2}=\sum_{k=0}^{n_{1}}\left[\hat{y}_{k}^{2}-\bar{y}_{1}\right]^{2}, \quad N_{1}+r, N_{2}+r$ - the number of basic splines.
The $F$ statistics has the Snedecor distribution with $n_{1}-N_{2}-r$ and $N_{2}-N_{1}$ degrees of freedom. It enables to test the hypothesis that the difference in variance of both regression functions is equal to zero. From the Snedecor distribution tables, for a given level of significance $a$ and with $n_{1}-N_{2}-r$ and $N_{2}-N_{1}$ degrees of freedom we read the critical value $F_{k r y t y c z n e}$ If $F \geq F_{\text {krytyczne }}$, then the hypothesis that the two variances are 
equal is rejected and it means that the regression functions differ from each other.

If the matching coefficients differ slightly with a larger number of basic splines, there is no clear need to expand the regression function. The use of an excessive number of basic functions significantly extends the calculation time.

To assess the correctness of the determined equations (12) (13), a test checking whether the rest of models $\widetilde{h}_{k}-h_{m k}, \widetilde{\psi}_{k}-\psi_{m k}$ undergoes the first - order autocorrelation. Then the von Neuman test [6] can be used to check it.

\section{CONCLUSION / Zaključak}

The method of identifying selected underwater motion equations presented in the article allows to obtain differential equations describing the change of the depth of immersion and the trim angle for any change in residual buoyancy. The analyzed case of filling the aft compensation tank is an example of the possibility of the described method. The accuracy of identification depends on the order of the differential equation and on the accuracy of the approximation of the input and output signals. The determined equations of movement of the submarine can be used for optimal control in the vertical plane.

The advantage of the algorithm of signal approximation is that the measurement data do not have to be registered in equidistant moments. The formulas of scalar products of the basic functions of the third degree spline can be determined in an analytic way and then the formulas (12) do not contain any definite integrals. This is important in numerical calculations. In this way, the time is significantly reduced and also the calculation error is reduced.
The elaborated method of identification can be used to determine the optimal ratios of mathematical models describing systems: economic, biological, mechanical, etc.

\section{REFERENCES / Literatura}

[1] Domachowski Z., Ghaemi M. 2019. Okrętowe układy automatyki. Wydawnictwo Politechniki Gdańskiej. Gdańsk.

[2] Niemiec L., Zellma M. 1988. Algorytm identyfikacji układu dynamicznego za pomocą bazowych funkcji sklejanych stopnia trzeciego. Zeszyty Naukowe AMW. 3/98. $105-131$.

[3] Nomoto K., Taguchi T., Honda K., Hirano S. 1957. On the Steering Qualities of Ships. ISP, Vol. 4. No.35. https://doi.org/10.3233/isp-1957-43504

[4] Stẹpień Z. 1981. Badanie wpływu pływalności szczatkowej na parametry ruchu okrętu podwodnego. Praca magisterska. WSMW Gdynia.

[5] Stechkin, S. B.; Subbotin, Yu. N. 1976. Splines in numerical mathematics. Moscow.

[6] Wysocki H.. 2006. Zastosowanie nieklasycznego rachunku operatorów do identyfikacji liniowych układów Dynamicznych. Polska Akademia Nauk. Instytut Badań Systemowych. Seria: Badania Systemowe, tom 48. Warszawa.

[7] Wysocki H., Zellma M. 1995. Modulating element method in the identification of a generalized dynamical system. Applicationes Mathematicae. 22, 4. 447467. https://doi.org/10.4064/am-22-4-447-467

[8] Zawiałow, J.; Kwasow, B. 1980. Splines methods. Science. Moscow.

[9] Załęska-Fornal, A.; Zellma, M. 2002. Application of Basic Splines to the Identification of Sailing Object Equations. ZN Nr 65. Wyższa Szkoła Morska w Szczecinie. EXPLO-SHIP. 375-386.

[10] Załęska-Fornal, A; Zellma, M. 2012. Zastosowanie wielomianowych funkcji sklejanych do identyfikacji równania opisującego zmiany kąta przegłębienia okrętu podwodnego. Czasopismo Technika Transportu Szynowego. Nr 9. CD. ISSN 1232-3829.

[11] Zellma, M. 1994. Modelowanie układu dynamicznego za pomocą funkcji sklejanych stopnia piątego. Zeszyty Naukowe AMW. 1/120. 97-107.

[12] Zellma, M.; Załęska-Fornal, A. 2004. Krzywoliniowa funkcja regresji w bazie funkcji sklejanych. Zeszyty Naukowe. AMW, Rok XLV. Nr3 (158). 119-134.

[13] Zellma, M.; Załęska-Fornal, A. XLVI. Opis procesów losowych za pomocą L-funkcji sklejanych. Zeszyty Naukowe. AMW. Nr 3 (162). 145-160.

[14] Marek Zellma, Agata Załęska-Fornal. 2019. Description of the dynamic characteristic of the floating objects by means of the smoothing splines. 1st International Conference of Maritime Science \& Technology Naše more. Conference proceedıngs. Dubrovnik, Croatia 17 - 18 October 2019. 666-678. 